\title{
KEBUTUHAN PERAWATAN GIGI PADA ANAK BERKEBUTUHAN KHUSUS DI SEKOLAH LUAR BIASA TAMAN PENDIDIKAN ISLAM MEDAN
}

\author{
Essie Octiara, Siti Salmiah, Zulfi Amalia, Luthfiani \\ Departemen Ilmu Kedokteran Gigi Anak \\ FKG USU Medan \\ e-mail: eoctiara@gmail.com
}

\begin{abstract}
Abstrak
Anak Berkebutuhan Khusus (ABK) yaitu seseorang yang mempunyai hambatan perilaku, fisik maupun intelektual yang mengharuskan dokter mengubah pendekatan kepadanya dengan berbagai cara untuk melakukan perawatan. ABK merupakan kelompok berisiko tinggi terhadap masalah kesehatan terutama karies gigi dan penyakit periodontal, namun kenyataannya sering mereka terlambat untuk mendapatkan perawatan gigi atau tidak pernah mendapatkan perawatan tersebut. Tujuan penelitian adalah mengetahui prevalensi dan pengalaman karies serta kebutuhan perawatan gigi pada anak berkebutuhan khusus di sekolah luar biasa Taman Pendidikan Islam di kota Medan. Penelitian dilakukan secara survei deskriptif. Besar sampel adalah 96 orang ABK berusia 5-29 tahun. Pemeriksaan karies secara klinis menggunakan indeks def-t/ DMF-T (WHO) dan indeks Treatment Need Indeks (TNI) yang dimodifikasi. Hasil penelitian diperoleh prevalensi karies anak ABK sebesar 92,71\%. Pengalaman karies gigi sulung sebesar $2,28 \pm 3,25$; sedangkan pengalaman karies gigi permanen sebesar $3,02 \pm 2,98$. Berdasarkan tingkat kebutuhan perawatan gigi (TNI) maka tingkat kebutuhan perawatan sebesar 656 gigi atau setiap anak membutuhkan rerata perawatan gigi sebesar 6,83 gigi, dengan tiga perawatan yang paling dibutuhkan adalah restorasi satu permukaan sebesar 2,49 gigi, kemudian diikuti dengan pencabutan gigi sebesar 1,43 gigi dan perawatan pulpa sebesar 0,70 gigi. Disimpulkan tingkat kesehatan gigi pada ABK masih cukup rendah, begitu juga dengan pemanfaatan fasilitas kesehatan gigi.
\end{abstract}

Kata kunci: anak berkebutuhan khusus, karies gigi, pengalaman karies, indeks kebutuhan perawatan

\begin{abstract}
Children with Special Needs is a person who has behavioral, physical and intellectual barriers that make doctor have to change approach with various ways to do the treatment. Children with special needs is a high-risk group for health problems, especially dental caries and periodontal disease, but in fact they are often too late to get dental treatment or never get the treatment. The purpose of this study was to determine the prevalence and experience of caries and dental care needs in children with special needs atSLB Taman Pendidikan Islam in Medan. The research was conducted by descriptive survey. The sample was 96 children with special needs with aged between 5-29 years old. Clinical caries examination using def-t / DMF-T (WHO) index and modified Treatment Need Index (TNI). The study is represent that the prevalence of children's caries is $92,71 \%$. Experience of dental caries is 2,28+3,25; while the permanent dental caries experience was 3,02 $\pm 2,98$. Based on Treatment Need Index (TNI), the level of dental care needs was 656 teeth or average dental treatment of each child requires was 6.83 teeth, with the three most needed treatment is a surface restoration was 2.49 teeth, followed by tooth extraction was 1.43 teeth and pulp treatment was 0.70 teeth. From the study it can be concluded that the level of dental hygiene in the chidren with special needs was still quite low, as well as the utilization of dental facilities.
\end{abstract}

Keywords: children with special needs, caries, experience of dental caries, treatment need index 
Octiara, E. et al. Kebutuhan Perawatan Gigi Pada Anak Berkebutuhan Khusus di Sekolah Luar Biasa...

\section{PENDAHULUAN}

Defenisi Anak Berkebutuhan Khusus (ABK) dalam bidang kedokteran anak yaitu seseorang yang mempunyai hambatan perilaku, fisik maupun intelektual yang mengharuskan dokter mengubah pendekatan kepadanya dengan berbagai cara untuk melakukan perawatan (Feasby \& Wright, 1975). ${ }^{1}$ Klasifikasi terbaru dalam menentukan ABK menurut panduan kurikulum sekolah luar biasa tahun 2003 yaitu: Visually Handicaped (Tuna Netra), Hearing Imparement ( Tuna Rungu), Mentally Retardation (Tuna Grahita), Physically Handicaped (Tuna Daksa), Behavior/ Emotionally Disordered (Tuna Laras), Tuna Wicara, Tuna Ganda. Klasifikasi kemudian berkembang lagi dengan menambahkan: HIV Aids, Gifted (Potensi Kecerdasan Istimewa , IQ>125), Talented (Potensi Bakat Istimewa/ Multipel intelegensi: bahasa, logico matematik, bodily kinesthetic, musical dll), Kesulitan Belajar (Hiperaktif), ADD/ADHD, disleksia, disgraphia, dysphasia/bicara dll), Lambat belajar (IQ=70-90), Autis, Korban penyalahgunaan narkoba dan Indigo. ${ }^{2}$

Keberadaan ABK semakin lama semakin meningkat. Badan Pusat Statistik dan Departemen Sosial tahun 2003 menyebutkan bahwa jumlah ABK di Indonesia sekitar 1,48 juta jiwa atau 0,7\% dari jumlah penduduk Indonesia. $^{3}$ Badan Pusat Statistik (BPS) tahun 2016 menyebutkan ABK mengalami kenaikan menjadi 1,6 juta jiwa. ${ }^{4}$ Namun kemungkinan jumlah ABK lebih besar dari data BPS, hal ini berdasarkan asumsi PBB yang menyatakan bahwa paling sedikit 10 persen anak usia sekolah (5-14 tahun) menyandang kebutuhan khusus. ${ }^{5}$

Anak-anak berkebutuhan khusus merupakan kelompok berisiko tinggi terhadap masalah kesehatan, sehingga membutuhkan bantuan dan kerjasama dengan orang lain untuk mendapatkan dan memelihara kesehatan, termasuk dalam menjaga kesehatan gigi dan mulut mereka. Kondisi rongga mulut ini sangat dipengaruhi oleh faktor usia (terutama anak yang masih sangat kecil), keparahan gangguan/kelainan, serta kondisi lingkungan dimana anak sangat tergantung pada orang tua, saudara kandung, ataupun pengasuh dalam merawat rongga mulutnya. ${ }^{6,7}$

Prevalensi karies ABK tidak terlalu berbeda dengan anak normal, namun pada anak ABK lebih banyak dijumpai karies gigi yang tidak dirawat. Peneliti lain menemukan lebih banyak ditemukan karies dan gigi yang hilang karena karies. Peneliti lain menemukan kebersihan rongga mulut $\mathrm{ABK}$ pada kategori buruk dengan insiden penyakit ginginva dan periodontal lebih tinggi dibanding anak normal, namun hal ini tergantung pada derajat dan tipe $\mathrm{ABK}^{8}$

Sebagian besar anak-anak berkebutuhan khusus membutuhkan tindakan perawatan gigi untuk mengatasi masalah giginya, namun kenyataannya sering mereka terlambat untuk mendapatkan perawatan gigi atau tidak pernah

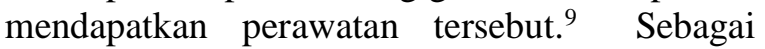
tenaga kesehatan, kita perlu mengetahui kebutuhan perawatan gigi pada ABK ini. Pengukuran kebutuhan perawatan karies gigi, penting untuk memperkirakan biaya, waktu, dan tenaga kesehatan dalam perencanaan suatu program kesehatan gigi. Indeks pengukuran untuk kebutuhan perawatan dapat digunakan Treament Need Index (TNI) yang dikeluarkan oleh WHO. TNI memberikan deskripsi yang lebih akurat mengenai tingkat keparahan karies dibandingkan indeks DMF-T.

Indeks TNI membagi atas 7 dasar tingkatan perawatan yaitu: (0) tidak ada kebutuhan perawatan; (1) perawatan preventif; (2) fisur silen; (3) restorasi inisial; (4) restorasi moderat; (5) restorasi advanced; (6) perawatan radikal seperti terapi pula, prostetik dan ekstraksi. ${ }^{10}$ Tujuan penelitian ini adalah mengetahui prevalensi dan pengalaman karies serta kebutuhan perawatan gigi pada anak berkebutuhan khusus di sekolah luar biasa Taman Pendidikan Islam di kota Medan.

\section{METODE}

Penelitian dilakukan secara survei deskriptif. Populasi adalah anak sekolah luar biasa Taman Pendidikan Islam di kota Medan adalah 170 orang, namun yang aktif bersekolah 
Octiara, E. et al. Kebutuhan Perawatan Gigi Pada Anak Berkebutuhan Khusus di Sekolah Luar Biasa...

secara rutin hanya 120 orang anak. Pada penelitian ini dari 120 orang anak, hanya 96 orang anak yang bersedia diperiksa giginya. Anak berkebutuhan khusus yang bersekolah memiliki keterbatasan yaitu: tuna rungu, tuna grahita, tuna wicara, tuna ganda, autis, dan down sindrom.

Pemeriksaan karies secara klinis dilakukan menggunakan kaca mulut dan probe dengan penerangan sinar matahari dan indeks def-t dan DMF-T (WHO).
Kebutuhan perawatan gigi diperiksa menggunakan indeks Treatment Need Indeks (TNI) yang dimodifikasi berdasarkan penelitian Wy PJ dan Wyk C. ${ }^{11}$ Kebutuhan perawatan gigi terbagi atas 6 yaitu Preventif, Restorasi satu permukaan dan Restorasi dua permukaan, Mahkota (SSC)+Veener, Perawatan Pulpa dan Ekstraksi, Prostetik/Space maintainer. Pengalaman karies dan kebutuhan perawatan dihitung berdasarkan usia dan jenis kelamin anak.

\section{HASIL}

Anak berkebutuhan khusus yang bersedia dilakukan pemeriksaan gigi pada sekolah luar biasa Taman pendidikan Islam sejumlah 96 orang. Usia 9-12 tahun paling banyak dilakukan pemeriksaan gigi $(30,21 \%)$ kemudian diikuti usia 5-8 tahun $(22,91 \%)$, usia 13-15 tahun (16,67\%), usia 16-18 tahun $(16,67 \%)$, usia $22-29$ tahun $(7,29 \%)$ dan $19-21$ tahun $(6,25 \%)$. Jenis kelamin antara laki-laki $(41,6 \%)$ dan perempuan $(43,4 \%)$ hampir seimbang yang bersedia dirawat (Tabel 1).

Tabel 1. Distribusi Pasien Anak Berkebutuhan Khusus Berdasarkan Usia dan Jenis Kelamin

\begin{tabular}{lcc}
\hline \multicolumn{1}{c}{ Kriteria } & $\mathrm{n}$ & $\%$ \\
\hline Usia & & \\
5-8 tahun & 22 & 22,91 \\
9-12 tahun & 29 & 30,21 \\
$13-15$ tahun & 16 & 16,67 \\
$16-18$ tahun & 16 & 16,67 \\
19-21 tahun & 6 & 6,25 \\
22-29 tahun & 7 & 7,29 \\
& & \\
\hline Jenis Kelamin & & 41,6 \\
Laki-laki & 47 & 43,4 \\
Perempuan & 49 & 100 \\
Jumlah & 96 & \\
\hline
\end{tabular}

Prevalensi karies pada 96 orang anak berkebutuhan khusus sebanyak 92,71\%. Berdasarkan jenis kelamin, prevalensi karies pada anak laki-laki sebesar 95,74\% sedangkan anak perempuan sebesar 89,80\%. Prevalensi karies $100 \%$ dimiliki pada kategori usia13-15 tahun, 19-21 tahun dan 22-29 tahun (Tabel 2). 
Octiara, E. et al. Kebutuhan Perawatan Gigi Pada Anak Berkebutuhan Khusus di Sekolah Luar Biasa...

Tabel 2. Prevalensi Karies Berdasarkan Usia dan Jenis Kelamin

\begin{tabular}{lccccc}
\hline \multicolumn{1}{c}{ Kriteria } & $\mathrm{n}$ & \multicolumn{2}{c}{ Karies } & \multicolumn{2}{c}{ Bebas Karies } \\
\hline Usia & & $\mathrm{n}$ & $\%$ & $\mathrm{n}$ & $\%$ \\
5-8 tahun & 22 & 21 & 95,45 & 1 & 13,79 \\
9-12 tahun & 29 & 25 & 86,21 & 4 & 0 \\
13-15 tahun & 16 & 16 & 100 & 0 & 12,5 \\
16-18 tahun & 16 & 14 & 87,5 & 2 & 0 \\
19-21 tahun & 6 & 6 & 100 & 0 & 0 \\
22-29 tahun & 7 & 7 & 100 & 0 & \\
& & & & & 4,26 \\
Jenis Kelamin & & & & & 10,20 \\
Laki-laki & 47 & 45 & 95,74 & 2 & 7,29 \\
Perempuan & 49 & 44 & 89,80 & 5 & \\
\hline Jumlah & 96 & 89 & 92,71 & 7 & \\
& & & & & \\
\hline
\end{tabular}

Rerata jumlah gigi yang dimiliki anak berkebutuhan khusus sebanyak 25,10 $\underline{3,44}$ gigi, sedangkan berdasarkan hasil pemeriksaan klinis ditemukan rerata hanya $19,78 \pm 4,98$ gigi yang sehat. Keadaan ini perlu mendapatkan perhatian bagi para tenaga kesehatan gigi karena gigi yang rusak dimiliki anak berkebutuhan khusus TPI Medan cukup tinggi, sehingga kebutuhan perawatan juga tentunya akan tinggi (Tabel 3).

Tabel 3. Distribusi Rerata Jumlah Gigi dan Gigi Sehat pada Pasien Anak Berdasarkan Usia dan Jenis Kelamin

\begin{tabular}{lccc}
\hline \multicolumn{1}{c}{ Kriteria } & $\mathrm{n}$ & $\begin{array}{c}\text { Rerata Jumlah } \\
\text { Gigi }\end{array}$ & $\begin{array}{c}\text { Rerata Jumlah Gigi } \\
\text { Sehat }\end{array}$ \\
\hline Usia & & & \\
$5-8$ tahun & 22 & $22,09 \pm 2,35$ & $16,14 \pm+4,27$ \\
$9-12$ tahun & 29 & $24,38+2,68$ & $19,58+4,47$ \\
$13-15$ tahun & 16 & $27,75 \pm 1,65$ & $22,62 \pm 2,68$ \\
$16-18$ tahun & 16 & $26,19 \pm 4,26$ & $20,75 \pm 6,13$ \\
$19-21$ tahun & 6 & $28,00 \pm 00$ & $21,17 \pm 4,62$ \\
$22-29$ tahun & 7 & $27,43 \pm 1,62$ & $23,43 \pm 2,94$ \\
& & & \\
\hline Laki-laki & 47 & $25,06 \pm 3,51$ & $19,79 \pm 4,85$ \\
Perempuan & 49 & $25,14 \pm 3,41$ & $19,78 \pm+5,14$ \\
\hline Jumlah & 96 & $25,10 \pm 3,44$ & $19,78 \pm+4,98$ \\
\hline
\end{tabular}


Octiara, E. et al. Kebutuhan Perawatan Gigi Pada Anak Berkebutuhan Khusus di Sekolah Luar Biasa...

Pengalaman karies gigi sulung anak berkebutuhan khusus Medan sebesar 2,28+3,25, sedangkan pengalaman karies gigi permanen sebesar 3,02 $\pm 2,98$. Berdasarkan usia anak, anak usia 5-8 tahun memiliki paling tinggi pengalaman karies gigi sulungnya yaitu sebesar 5,32 $\pm 4,07$ ); kemudian diikuti oleh usia 9-12 tahun sebesar 2,45 $\pm 2,84$. Usia 13-15 tahun dan 16-18 tahun masih memiliki gigi sulung karena persistensi. Pengalaman karies gigi permanen paling tinggi dimiliki oleh anak usia 19-21 tahun sebesar $6,83 \pm 4,62$ (Tabel 4).

Berdasarkan jenis kelamin, pengalaman karies gigi sulung paling banyak dimiliki anak perempuan sebesar $2,67 \pm 3,3$. Pengalaman karies gigi permanen paling banyak dimiliki anak laki-laki sebesar $3,40 \pm 2,91$ (Tabel 4).

Tabel 4. Pengalaman Karies Berdasarkan Usia dan Jenis Kelamin

\begin{tabular}{|c|c|c|c|c|c|c|c|c|c|}
\hline Kriteria & $\mathrm{N}$ & d & $\mathrm{e}$ & $\mathrm{f}$ & def-t & $\mathrm{D}$ & M & $\mathrm{F}$ & DMF-T \\
\hline \multicolumn{10}{|l|}{ Usia } \\
\hline & 2 & $4,14 \underline{+3,8}$ & $1,18 \pm 1,9$ & & $5,32 \pm 4,0$ & $0,59 \pm 1,0$ & $0,05 \pm 0,2$ & & $0,64 \pm 1,0$ \\
\hline \multirow[t]{2}{*}{ 5-8 tahun } & 2 & $2-$ & $2-$ & 0 & 7 & 5 & $\overline{1}$ & 0 & 5 \\
\hline & 2 & $1,66 \pm 2,3$ & $0,93 \pm 1,0$ & & $2,45 \pm 2,8$ & $1,93 \pm 1,8$ & $0.41 \pm 0,8$ & $0,03 \pm 0,1$ & $2,34 \pm 2,2$ \\
\hline 9-12 tahun & 9 & 6 & 6 & 0 & $\overline{4}$ & 7 & $\overline{7}$ & 8 & $\overline{4}$ \\
\hline $13-15$ & 1 & $1,33 \pm 2,2$ & & & $1,25 \pm 2,2$ & $3,25 \pm 1,8$ & $0,62 \pm 1,1$ & & $3,87 \pm 1,6$ \\
\hline tahun & 6 & 8 & 0 & 0 & $\overline{4}$ & $\overline{4}$ & 5 & 0 & $\overline{7}$ \\
\hline $16-18$ & 1 & & & & $0,62 \pm 1,1$ & $3,87 \pm 2,8$ & $0,94 \pm 1,3$ & & $4,81 \pm 3,5$ \\
\hline tahun & 6 & $0,5 \pm 0,82$ & 0 & 0 & $\overline{4}$ & $\overline{7}$ & 9 & 0 & 8 \\
\hline $19-21$ & & & & & & $6,50 \pm 4,3$ & $0,33 \pm 0,5$ & & $6,83 \pm 4,6$ \\
\hline tahun & 6 & 0 & 0 & 0 & 0 & 7 & 1 & 0 & 2 \\
\hline $22-29$ & & & & & & $2,43 \pm 1,1$ & $1,28 \pm 2,2$ & & $3,71 \pm 2,9$ \\
\hline tahun & 7 & 0 & 0 & 0 & 0 & 3 & 1 & 0 & 8 \\
\hline \multicolumn{10}{|c|}{ Jenis Kelamin } \\
\hline & & $1,52 \pm 2,7$ & $0,39 \pm 0,8$ & & $1,87 \pm 3.0$ & $2,64 \pm 2,3$ & $0,74 \pm 1,4$ & $0,02+0,1$ & $3,40 \pm 2,9$ \\
\hline Laki-laki & 47 & $\overline{4}$ & 3 & 0 & 8 & 1 & $\overline{1}$ & 4 & 1 \\
\hline Perempu & & $1,94 \pm 2,8$ & $0,77 \pm 1,4$ & & $2,67 \pm 3,3$ & $2,39 \pm 2,7$ & $0,29 \pm 0,6$ & & $2,65 \pm 3,0$ \\
\hline an & 49 & 9 & 9 & 0 & 8 & 8 & 1 & 0 & 2 \\
\hline & & $1,74 \pm 2,8$ & $0,59 \pm 1,2$ & & $2,28 \pm 3,2$ & $2,51 \pm 2,5$ & $0,51 \pm 2,5$ & $0,01+0,1$ & $3,02 \pm 2,9$ \\
\hline Jumlah & 96 & 1 & 2 & 0 & 5 & 5 & $\overline{5}$ & 0 & 8 \\
\hline
\end{tabular}

Berdasarkan pemeriksaan klinis, kebutuhan total perawatan gigi pada anak berkebutuhan khusus secara keseluruhan sebesar 656 gigi atau masing-masing anak membutuhkan 6,83 gigi untuk dilakukan perawatan. Kebutuhan perawatan yang terbanyak adalah perawatan restorasi satu permukaan dengan jumlah total sebesar 239 restorasi atau masing-masing anak membutuhkan perawatan restorasi sebesar 2,49 $\pm 2,30$ (Tabel 5). 
Octiara, E. et al. Kebutuhan Perawatan Gigi Pada Anak Berkebutuhan Khusus di Sekolah Luar Biasa...

Tabel 5. Kebutuhan Perawatan Pasien Anak Berdasarkan Usia dan Jenis Kelamin

\begin{tabular}{|c|c|c|c|c|c|c|c|c|c|c|c|c|c|c|c|c|}
\hline \multirow{3}{*}{ Kriteria } & \multirow{3}{*}{$\mathrm{N}$} & \multirow{2}{*}{\multicolumn{2}{|c|}{$\begin{array}{c}\text { Preventif } \\
\text { FS+RP }\end{array}$}} & \multirow[b]{2}{*}{ Restorasi 1} & \multirow{2}{*}{\multicolumn{2}{|c|}{ Restorasi 2}} & \multirow{2}{*}{\multicolumn{2}{|c|}{$\begin{array}{c}\text { Mahkota/Veen } \\
\text { er }\end{array}$}} & \multirow{2}{*}{\multicolumn{2}{|c|}{ Pulpa }} & \multirow{2}{*}{\multicolumn{2}{|c|}{ Ekstraksi }} & \multirow{2}{*}{\multicolumn{2}{|c|}{ Prostestik/SM }} & \multirow{2}{*}{\multicolumn{2}{|c|}{ Jumlah }} \\
\hline & & & & & & & & & & & & & & & & \\
\hline & & $\mathrm{n}$ & rerata & $\mathrm{n} \quad$ rerata & $\mathrm{n}$ & rerata & $\mathrm{n}$ & rerata & $\mathrm{n}$ & rerata & $\mathrm{n}$ & rerata & $\mathrm{n}$ & rerata & $\mathrm{n}$ & rerata \\
\hline \multicolumn{17}{|l|}{ Usia } \\
\hline 5-8 tahun & 22 & 10 & $\begin{array}{c}0,45 \pm 0,8 \\
5 \\
0,86 \pm 2,0\end{array}$ & $\begin{array}{c}62 \\
2,82 \pm 2,36\end{array}$ & 16 & $0,73 \pm 1,32$ & 11 & $\begin{array}{c}0,50 \pm 1 \\
, 71 \\
0,45 \pm 0\end{array}$ & 16 & $\begin{array}{c}0,73 \pm 1,3 \\
2 \\
1,03 \pm 1,6\end{array}$ & 28 & $\begin{array}{l}1,27 \pm 1,88 \\
1,65 \pm, 1,4\end{array}$ & 1 & $\begin{array}{c}0,04 \pm 0,2 \\
1 \\
0,30 \pm 0,8\end{array}$ & 144 & 6,55 \\
\hline $9-12$ tahun & 29 & 25 & 3 & $582,0 \pm 2,37$ & 14 & $0,48 \pm 1,33$ & 13 & 89 & 30 & 1 & 48 & $\overline{0}$ & 9 & 1 & 197 & 6,79 \\
\hline 13-15 tahun & 16 & 12 & $\frac{0,75 \pm 1,4}{8}$ & $\begin{array}{c}33 \\
2,06 \pm 1,62\end{array}$ & 6 & $0,37 \pm 1,02$ & 8 & $\begin{array}{c}0,50 \pm 0 \\
, 96\end{array}$ & 10 & $\frac{0,62 \pm 0,9}{6}$ & 31 & $1,94 \pm 2,26$ & 9 & $\frac{0,56 \pm 1,0}{9}$ & 109 & 6,81 \\
\hline 16-18 tahun & 16 & 14 & $\frac{0,87 \pm 2,0}{9}$ & $\begin{array}{c}45 \\
2,81 \pm 2,00\end{array}$ & 7 & $0,44 \pm 0,81$ & 7 & $\begin{array}{l}0,44 \pm 0 \\
, 72\end{array}$ & 9 & $\frac{0,56 \pm 0,8}{1}$ & 18 & $1,12 \pm 1,39$ & 30 & $\frac{1,87 \pm 4,4}{4}$ & 130 & 8,12 \\
\hline 19-21 tahun & 6 & 0 & 0 & $\begin{array}{c}25 \\
4,17 \pm 4,12\end{array}$ & 11 & $1,83 \pm 3,12$ & 3 & $\underset{, 55}{0,50 \pm 0}$ & 3 & $\frac{0,50 \pm 0,5}{5}$ & 1 & $0,17 \pm 0,41$ & 2 & $\frac{0,33 \pm 0,5}{2}$ & 45 & 7,5 \\
\hline 22-29 tahun & 7 & 0 & 0 & $\begin{array}{c}16 \\
2,29 \pm 1,25\end{array}$ & 2 & $0,28 \pm 0,41$ & 0 & 0 & 0 & 0 & 11 & $1,57 \pm 2,15$ & 2 & $\begin{array}{c}0,29+0,4 \\
9\end{array}$ & 31 & 4,42 \\
\hline \multicolumn{17}{|c|}{ Jenis Kelamin } \\
\hline Laki-laki & 47 & 19 & $\frac{0,40 \pm 1,1}{3}$ & $\begin{array}{c}116 \\
2,46 \pm 2,22\end{array}$ & 31 & $0,67 \pm 1,59$ & 16 & $\begin{array}{c}0,34 \pm 0 \\
, 73\end{array}$ & 29 & $\begin{array}{c}0,62 \pm 1,0 \\
3\end{array}$ & 68 & $1,45 \pm 1,65$ & 43 & $\frac{0,91 \pm 2,7}{4}$ & 322 & 6,85 \\
\hline Perempuan & 49 & 42 & $\begin{array}{c}0,85 \pm 1,9 \\
0\end{array}$ & $\begin{array}{c}123 \\
2,51 \pm 2,40 \\
\end{array}$ & 25 & $0,51 \pm 1,10$ & 26 & $\begin{array}{c}0,53 \pm 1 \\
, 31 \\
\end{array}$ & 39 & $\begin{array}{c}0,80 \pm 1,5 \\
9\end{array}$ & 69 & $1,41 \pm 1,80$ & 10 & $\begin{array}{c}0,20 \pm 0,5 \\
0\end{array}$ & 334 & 6,82 \\
\hline Jumlah & 96 & 61 & $\begin{array}{c}0,63 \pm 1,5 \\
8\end{array}$ & $\begin{array}{c}239 \\
2,49 \pm 2,30\end{array}$ & 56 & $0,59 \pm 1,36$ & 42 & $\begin{array}{c}0,43 \pm 1 \\
, 06\end{array}$ & 68 & $\frac{0,70 \pm 1,3}{4}$ & 137 & $1,43 \pm 1,72$ & 53 & $\frac{0,55 \pm 1,9}{8}$ & 656 & 6,83 \\
\hline
\end{tabular}

Keterangan:

$\mathrm{N}=$ jumlah orang

$\mathrm{n}=$ jumlah gigi

$\mathrm{FS}=$ Fisur silen

$\mathrm{RP}=$ restorasi preventif

\section{$\mathrm{SM}=$ space maintainer}

\section{PEMBAHASAN}

Hasil pemeriksaan klinis diperoleh, prevalensi karies pada anak berkebutuhan khusus di sekolah luar Taman Pendidikan Islam Medan usia 5-29 tahun sebesar 92,71\% (Tabel 2). Prevalensi karies ini lebih tinggi dibandingkan penelitian Shenoy et.al (2011) yang mendapatkan prevalensi karies pada 262 orang ABK usia 4-40 tahun sebesar 75,19\%. ${ }^{12}$

Berdasarkan usia, prevalensi karies yang tertinggi pada kelompok usia 13-15 tahun, 19-21 tahun dan 22-29 tahun sebesar 100\%, kemudian diikuti dengan kelompok usia 5-8 tahun sebesar $95,45 \%$, kelompok usia 16-18 tahun sebesar
87,5\% dan kelompok usia 9-12 tahun sebesar $86,21 \%$ (Tabel 2).

Pemeliharaan kesehatan gigi pada anak ABK masih perlu ditingkatkan, mengingat dari $25,10 \pm 3,44$ gigi yang ada di mulut pasien, $19,78 \pm 4,98$ gigi yang masih dalam keadaan sehat. Tidak ada beda antara jenis kelamin untuk penjagaan kesehatan gigi mengingat jumlah gigi yang sehat pada laki-laki sebesar 19,79 $\pm 3,85$ sedangkan pada perempuan sebesar $19,78 \pm 5,13$ (Tabel 3).

Pengalaman karies gigi sulung pada kelompok usia 5-8 tahun adalah 5,32 $\pm 4,07$ sedangkan pengalaman karies gigi permanenya $0,64 \pm 1,05$ (Tabel 4). Pengalaman karies gigi sulung $\mathrm{ABK}$ pada penelitian ini lebih tinggi 
Octiara, E. et al. Kebutuhan Perawatan Gigi Pada Anak Berkebutuhan Khusus di Sekolah Luar Biasa...

dibandingkan penelitian Hanoush \& Helail (2016) yaitu sebesar 3,9 (kelompok usia 6-9 tahun $)^{8}$ danjuga penelitian Folakemi et.al (2008) sebesar 1,46+2,69 (kelompok usia 6-10 tahun) ${ }^{13}$.Namun pengalaman karies gigi permanen pada penelitian ini lebih rendah yaitu 0,64 dibanding penelitian Hanoush \& Helail sebesar 3,34 . $^{8}$

Kelompok usia 9-12 tahun pada penelitian ini memiliki deft sebesar $2,45 \pm 2,84$ dan DMFT sebesar 2,34 $\pm 2,24$. Pengalaman karies gigi sulung maupun permanen kelompok usia ini lebih rendah dibanding penelitian Hanous \& Helal (2016) yang mendapatkan pada kelompok usia 10-12 tahun pengalaman karies gigi sulungnya sebesar 5,7 dan gigi permanennya sebesar $4,46 .^{8}$ Begitu juga kelompok usia 13-15 tahun, pengalaman karies gigi permanen pada penelitian ini lebih rendah dibanding penelitian Adhi \& Octavia $(2013)^{14}$ dan Hanous \& Helal (2016) (DMFT 3,87; 4,4; 7,45), namun lebih tinggi dibandingkan penelitian Folakemi et.al (2008) sebesar $0,5 \pm 1,26^{13}$. Pada kelompok usia 13-15 tahun pada penelitian ini masih ada pengalaman karies gigi sulung karena masih ada gigi sulung yang persistensi yang mengalami karies atau masih ada gigi sulung karies yang belum digantikan gigi permanennya.

Pengalaman karies kelompok usia 16-18 tahun pada penelitian ini lebih tinggi dibandingkan penelitian Folakemi et.al (2008) yaitu 4,81 dan 3,71. Begitu juga kelompok usia 22-29 tahun pada penelitian ini lebih tinggi dibandingkan penelitian Folakemi et.al yaitu $3,71 \pm 2,98$ berbanding $1,11 \pm 2,11 .^{13}$

Menurut $\mathrm{WHO},{ }^{15}$ pengalaman karies gigi sulung pada kelompok usia 5-8 tahun pada penelitian ini masuk dalam kategori tinggi. Pengalaman karies gigi permanen pada kelompok usia 19-21 tahun pada penelitian ini termasuk kedalam kategori sangat tinggi. Kelompok usia 16-18 tahun masuk dalam kategori tinggi, sedangkan kelompok usia 13-15 tahun masuk kedalam kategori sedang. Hal ini tentu perlu menjadi perhatian tenaga kesehatan untuk mengatasi masalah penyakit karies pada ABK di kota Medan.

Berdasarkan jenis kelamin, pada penelitian ini ditemukan pengalaman karies gigi sulung pada perempuan lebih tinggi dibanding anak laki-laki sebesar (deft $2,67+3,38$ vs $1,87+3,08)$. Hal ini berbeda dengan penelitian Adhi \& Octavia (2013) menemukan bahwa anak laki-laki lebih tinggi pengalaman karies gigi sulungnya dibandingkan anak perempuan $(4,33$ vs 3,6$).{ }^{14}$ Namun sebaliknya pada penelitian ini, pengalaman karies gigi permanen laki-laki lebih tinggi dibanding anak perempuan $(3,40 \pm 2,91$ vs $2,65 \pm 3,02)$, sedangkan penelitian Adhi \& Octavia (2013) menemukan DMFT anak perempuan sedikit lebih tinggi dibanding anak laki-laki (3,2 vs 3$)^{14}$, begitu juga penelitian Liu et.al (2014) menemukan DMFT anak perempuan lebih tinggi dibanding anak laki-laki $(1,9 \pm 2,1$ vs $1,4 \pm 1,9) .{ }^{16}$

Berdasarkan distribusi tingkat kebutuhan perawatan gigi (TNI) maka tingkat kebutuhan perawatan sebesar 656 gigi atau setiap anak membutuhkan rerata perawatan gigi sebesar 6,83 gigi. Perawatan yang paling banyak dibutuhkan adalah perawatan restorasi satu permukaan, kemudian diikuti dengan pencabutan gigi, perawatan pulpa, perawatan preventif (fisur silen dan restorasi preventif), restorasi dua permukaan, protesa/space maintainer dan mahkota (Tabel 5). Perawatan yang paling banyak dibutuhkan dalam penelitian ini sesuai dengan penelitian Jan et.al (2008) pada 127 orang ABK usia 5-22 tahun yang mendapatkan bahwa perawatan restorasi satu permukaan adalah perawatan yang paling banyak dibutuhkan, urutan kebutuhan perawatan selanjutnya adalah restorasi dua permukaan, fisur silen, perawatan pulpa, ekstraksi dan mahkota. ${ }^{17}$ Penelitian Shoenoy et.al juga menemukan urutan kebutuhan paling banyak pada ABK adalah restorasi satu permukaan, kemudian diikuti dengan restorasi dua permukaan, ekstraksi gigi, gigi tiruan/mahkota dan perawatan pulpa. ${ }^{12}$

Kebutuhan rerata perawatan restorasi satu permukaan pada penelitian adalah 2,49 gigi, berarti ada 3 gigi yang pelu dilakukan penambalan sederhana pada ABK. Kebutuhan rerata ekstraksi gigi cukup tinggi yaitu sebesar 1,43 gigi, yang berarti ABK membutuhkan 2 gigi untuk dilakukan pencabutan. Hal ini disebabkan banyak gigi sulung persistensi yang perlu dilakukan pencabutan gigi. ABK pada 
Octiara, E. et al. Kebutuhan Perawatan Gigi Pada Anak Berkebutuhan Khusus di Sekolah Luar Biasa...

sekolah ini sebagian besar tidak pernah berobat ke dokter gigi sehingga gigi molar sulung sering ditemukan persistensi pada ABK. Kebutuhan perwatan pulpa pada penelitian ini adalah 0,70 gigi sehingga minimal ada 1 gigi yang membutuhkan perawatan pulpa pada $\mathrm{ABK}$.

Berdasarkan usia, kebutuhan restorasi satu dan dua permukaan paling banyak dibutuhkan pada ABK kelompok usia 5-8 tahun. Kebutuhan ekstraksi gigi, mahkota, perawatan pulpa dan restorasi preventif paling banyak dibutuhkan pada kelompok usia 9-12 tahun. Perawatan prostetik paling banyak dibutuhkan pada kelompok usia 16-18 tahun (Tabel 5). Penelitian Jan et.al mendapatkan, kebutuhan perawatan restorasi satu permukaan dan fisur silen paling banyak pada kelompok usia 13-17 tahun. Kebutuhan restorasi dua permukaan paling banyak pada kelompok usia 8-12 tahun. Kebutuhan perawatan pulpa, ekstraksi gigi, dan mahkota paling banyak pada kelompok usia 1822 tahun. $^{17}$

Disimpulkan prevalensi karies pada ABK sangat tinggi, pengalaman karies gigi sulung pada kelompok usia 5-8 tahun termasuk kategori tinggi, pengalaman karies gigi permanen kelompok usia 19-21 tahun termasuk kategori sangat tinggi, kelompok usia 16-18 tahun kategori tinggi dan untuk semua kelompok usia memiliki tingkat filling begitu rendah. Kebutuhan perawatan gigi juga tinggi dengan kebutuhan restorasi yang paling banyak dibutuhkan.

Terimakasih diucapkan kepada Rektor USU atas dana biaya pengabdian BPPTN Universitas Sumatera Utara, sehingga penelitian ini dapat dilaksanakan.

\section{DAFTAR PUSTAKA}

1. Feasby WH, Wright GZ. The special child patient in: Behavior management in dentistry for children. Wright ed. London: GZ WB. Saunders Co, 1975: 129.

2. Dinas pendidikan Nasional Republik Indonesia. Panduan kurikulum sekolah luar biasa 2003, untuk pendidikan guru luar biasa (PLB), $2003: 4$.
3. Yayasan Peduli Kasih. Fokus utama dalam anak berkebutuhan khusus. Yayasan Peduli Kasih 2012: 5.

4. Bahron. Anak kebutuhan khusus di Indonesia capai 1,6 juta.3 Februari 2017. http:/// mirajnews.com (15 Oktober 2017)

5. Melisa F. Jumlah anak berkebutuhan khusus di Indonesia tinggi. 13 Juli 2013 http://nasional.republika.co.id (15 Oktober 2017)

6. Shaw L, MacLauiin ET, Foster TD. Dental study of handicapped children attending special schools in Birmingham, UK. Community Dent Oral Epidemiol 1986;14:24-27.

7. Prashanth GM, Chandu GN, MD Shafiulla. Dental caries experience among 6-18 years old blind children of residential school, Bangalore, Karnataka. J Indian Asso Public Health Dentistry 2005;6:18- 21.

8. Hanoush SMY, Helail B. The oral health of 6-15 year old special needs children in Baghdad. Int J Dent Scienc. And Researc. 2016, 4(5): 79-84.

9. Fulda, K.G., Johnson, K.L., Hahn, K., Lykens, K. Do unmet needs differ geographically for children with special health care needs? Matern. Child Health J. 2013; 17: 505-11.

10. Mann J, Sqan-Cohen HD, Asher RS, Amir E, Cohen S,Sarnat H. A treatment need index: A pilot study. Int. J Paediatr. Dent. 1993; 3(3): 129-34.

11. Wyk PJ, Wyk C. Oral health in South Africa. Int. Dent. J. 2004; 54: 373-7

12. Shenoy RP, Hegde V, Shenai PK. Dentition status, treatment needs and dental aesthetic index scores of individuals attending special schools. Indian J Community Med. 2011; 36(4): 301-3.

13. Folakemi A, Oredugba FA, Akindayomi Y. Oral health status and treatment needs of children and young adultsattending a day centre for individuals with special health care needs. BMC Oral Health2008, 8:30

14. Adhi YK, Octavia A. Perbedaan tingkat kejadian karies pada anak berkebutuhan khusus berdasarkan jenis kelamin di kelas 14 SDLB Widya Mulya, Pundong, Bantul, DIY. IDJ 2013; 2(2): 22-33. 
Octiara, E. et al. Kebutuhan Perawatan Gigi Pada Anak Berkebutuhan Khusus di Sekolah Luar Biasa...

15. WHO. Oral health information systems. http://who.int/oral_health (15 Oktober 2017).

16. Liu Z, Yu D, Luo W, Yang J, Lu J, Gao S, Li W, Zhao W. Impact of oral health behaviors on dental caries in children with intellectual disabilities in Guangzhou,
China. Int.J Environ Res. Public. Health 2014, 11: 11015-27.

17. Jain M, Mathur A, Kumar S, Dagli RJ, Duraiswamy P, Kulkarni S. Dentition status and treatment needs among children with impaired hearing attending a special school for the deaf and mute in Udaipur, India. $\mathbf{J}$ Oral Science 2008; 50(2): 161-5. 